\title{
MENTAL HEALTH OF A PERSON AS A CRITERION OF PERSONAL PARTICIPATION IN THE TRIAL DURING CRIMINAL PROCEEDINGS
}

DOI: 10.36740/WLek202012207

\author{
Vasyl Y. Tatsiy ${ }^{1}$, Olga I. Tyshchenko ${ }^{1}$, Ivan A. Titko² \\ 'YAROSLAV MUDRYI NATIONAL LAW UNIVERSITY, KHARKIV, UKRAINE \\ 2POLTAVA LAW INSTITUTE OF YAROSLAV MUDRYI NATIONAL LAW UNIVERSITY, POLTAVA, UKRAINE
}

\begin{abstract}
The aim of this work is to identify and analyze the key positions of the ECHR in the context of respect for the right to a fair trial (Article 6 of the European Convention on Human Rights (hereinafter - the Convention)) of a person suffering from mental disorders in criminal proceedings concerning the application of compulsory medical measures (hereinafter referred to as $(\mathrm{CMM})$; formulation of scientifically substantiated proposals for determining the restriction legality criteria of the right of a person suffering from a mental disorder to personal participation in the trial.

Materials and methods: During the preparation of the article, the following was processed: scientific research on ensuring the rights of persons suffering from mental disorders in criminal proceedings; provisions of international agreements on the provision of psychiatric care; the legal position of the ECHR on the observance of the right to a fair trial of persons suffering from mental disorders ( 6 decisions were analyzed in which the ECHR addressed these issues in the context of the requirements of Article 6 of the Convention); criminal procedural legislation of individual states; the results of a survey conducted by the authors of 88 judges (judges of local courts of Ukraine) on key issues of ensuring the participation of a person suffering from a mental disorder in a court hearing.

In the process of research a set of general scientific and special methods of cognition was used (comparative-legal method, systemic-structural method, generalization method, method of analysis and synthesis, method of sociological research, method of expert assessments, etc.).

Results: According to the results of the research: a) the legal positions of the ECHR to ensure the right of a person suffering from a mental disorder to a fair trial are identified and generalized (Article 6 of the Convention); b) criteria for the legality of restricting the right of a person suffering from a mental disorder to personal participation in the trial are proposed. Conclusions: An analysis of the ECHR's key positions led to the conclusion that there was a violation of a person's right to a fair trial in national case law (Article 6 of the Convention), due in part to the lack of clear criteria for legally restricting a person's right to a trial.
\end{abstract}

KEY WORDS: mental health, expert opinion, right to a fair trial, mental disorder, ECHR practice

Wiad Lek. 2020;73(12 p. II):2737-2742

\section{INTRODUCTION}

The current development of the case law of the ECHR shows a fairly high level of appeals to this European institution of persons suffering from mental disorders whose claims are violations of the right to liberty and security (Article $5 \$ 1$ (e) of the Convention) and the right to a fair trial (Article 6 of the Convention). The article will consider the key positions of the ECHR on the personal participation of a person suffering from a mental disorder in the trial from the standpoint of compliance with Art. 6 of the Convention right to a fair trial. We should note that some issues in this area were previously published by the authors of this article together with Olena A. Leiba [see at: 1]. However, in the framework of this study, the authors intend to develop scientific ideas aimed at addressing the issue of personal participation of persons with mental disorders in court proceedings in the context of international standards and legal positions of the ECHR to ensure the right to a fair trial (Art. 6 of the Convention).

\section{THE AIM}

The aim of this work is to identify and analyze the key positions of the ECHR in the context of respect for the right to a fair trial (Article 6 of the European Convention on Human Rights (hereinafter - the Convention)) of a person suffering from mental disorders in criminal proceedings concerning the application of compulsory medical measures (hereinafter referred to as CMM); formulation of scientifically substantiated proposals for determining the restriction legality criteria of the right of a person suffering from a mental disorder to personal participation in the trial.

\section{MATERIALS AND METHODS}

During the preparation of the article, the following was processed: scientific research on ensuring the rights of persons suffering from mental disorders in criminal proceedings; provisions of international agreements on the provision of psychiatric care; the legal position of the ECHR on the observance of the right to a fair trial of persons suffering from mental disorders ( 6 decisions were analyzed in which the ECHR addressed these issues in the context of the requirements of Article 6 of the Convention); criminal procedural legislation of individual states; the results of a survey conducted by the authors of 88 judges 
(judges of local courts of Ukraine) on key issues of ensuring the participation of a person suffering from a mental disorder in a court hearing.

In the process of research a set of general scientific and special methods of cognition was used (comparative-legal method, systemic-structural method, generalization method, method of analysis and synthesis, method of sociological research, method of expert assessments, etc.).

\section{RESULTS}

As it is noted in the special literature, "mental disorder (a term often used in mental health legislation and international literature on mental health tribunals) is recognized as a global health concern and is one that has attracted significant international attention" [2, p. 494]. The World Health Organization demonstrates dangerous statistics mental disorders are one of the top public health challenges in the WHO European Region, affecting about $25 \%$ of the population every year [3]. In the case of committing socially dangerous acts by persons suffering from mental disorders, the legislation of foreign countries provides for a special procedure for criminal proceedings. In general, the peculiarities of the proceedings against persons suffering from mental disorders are embodied at the level of international legal acts, such as: the Convention on Human Rights and Biomedicine of 4 April 1997; United Nations General Assembly Resolution Principles for the Protection of Persons with Mental Illness and the Improvement of Psychiatric Care, № 46/119 of 18 February 1992; Recommendation of the Committee of Ministers to member states on the legal protection of persons suffering from mental disorders who are involuntarily detained as patients, № $\mathrm{R}$ (83) 2 of 22 February 1983; Recommendation № 1235 on psychiatry and human rights of 01 January 1994, Recommendation 818 on the situation with mental illness of 08 October 1977, etc.

The analysis and generalization of the case law of the ECHR allows singling out certain ECHR approaches to the personal participation of a person suffering from a mental disorder in court proceedings.

1. A person suffering from a mental disorder shall have access to a court and the opportunity to be heard in person or through any form of legal representation (See at: $\$ 71$ Case of Shtukaturov v. Russia [4]; $\$ 62$ Case of Zagidulina v. Russia [5]; $\$ 39$ Case of Gorshkov v. Ukraine [6]). This position of the ECHR embodies the international legal standard provided for in Art. 6 of the Convention - the right to a fair trial. In its decisions on persons suffering from mental disorders, the ECHR has repeatedly recalled that from the very notion of a fair trial, it is clear that a person accused of a crime must be given the right to be present and to participate effectively in the trial (See at: $\$ 106$ Case of Romanov v. Russia; $\$ 100$ Case of Proshkin v. Russia). In addition, the ECHR considers alternative participation in the court hearing of its representatives to be a form of exercising the right to a personal presence in court. Thus, modern criminal procedure legislation of many states provides for double representation of the rights of a person suffering from a mental disorder, in the form of participation of a lawyer and a legal representative (the Criminal Procedure Code of the Russian Federation (Articles 437, 438); the CPC of Ukraine (Articles 512); the CPC of Moldova (Articles 493, 494); the CPC of Belarus (Articles 445, 446); the CPC of Kazakhstan (Articles 512, 513); the CPC of Kyrgyzstan (Articles 467, 468), the CPC of Poland (Articles 76, 79)) and others. Due to the particular vulnerability of a person suffering from a mental disorder, the mandatory participation of their representatives in criminal proceedings (in particular, in court proceedings) is of particular importance. After all, it provides an adequate level of protection of the rights and legitimate interests of a person whose mental disorder does not allow them to exercise their procedural rights independently.

However, at the present stage of development of case law there is a tendency towards the priority of ensuring personal participation in the trial of a person suffering from a mental disorder. For example, in Case of Zagidulina v. Russia the applicant was recommended hospitalization, with which Ms. Zagidulina disagreed. On the same day the hospital applied to the court for a sanction for the applicant's involuntary hospitalization. The trial was attended by a prosecutor, a psychiatrist and a representative of a psychiatric hospital, who requested a hearing in the applicant's absence as she could not attend the hearing on medical grounds. The hearing was held in the absence of the applicant and her representative ( $\$ 5-10)$. The ECHR emphasized that the applicant played a dual role in the proceedings: she was an interested party, and, at the same time, the main object of the court's examination. Therefore, hearing the applicant either in person or through some form of representation was indispensable for a "fair and proper procedure". Taking into consideration the applicant's clear and undisputed refusal to undergo any treatment and the domestic courts' awareness of this fact, which was reflected in their decisions, the need to ensure the applicant's right to be heard was ever more pressing (See at: $\$ 62$ of the Case of Zagidulina v. Russia) [5].

It should be noted that the ECHR has categorically stated in some cases that the participation of counsel and legal representative could not compensate for the absence of a person suffering from a mental disorder in the trial. This legal position has been demonstrated in a number of the ECHR cases. For example, in Case of Romanov v. Russia the Court noted that the psychiatrists' findings were identical as to the diagnosis, but differed in the choice of measures to be applied to the applicant: outpatient treatment or placement in a psychiatric hospital. The ECHR emphasized that such disagreement was of particular importance to the applicant's participation in the court hearing. The district court could not rule without a direct assessment of the applicant's testimony, and the presence of the applicant's lawyer could not compensate for his absence ( $\$ 111-112$ ) [7]. In Case of Proshkin v. Russia the ECHR criticized the following circumstances of the case. Thus, the trial court questioned the examination's findings 
and therefore considered it appropriate to re-examine the applicant's psychiatric examination. However, not receiving the results of the new examination in time, the court ruled to apply CMM to the applicant $(\$ 31)$. In this situation, it was particularly important for the judges to hear the applicant in person and to ascertain his state of health. The court could not rule without a direct assessment of the applicant's conduct and the evidence provided by him. The presence of the applicant's defense counsel and mother could not compensate for the applicant's inability to present his own arguments in court (\$104) [8].

Thus, the analysis of the above positions of the ECHR allows us to conclude that the ECHR recognizes: a) forms of implementation of the provisions of Art. 6 of the Convention right to a fair trial, personal participation in the trial of a person suffering from a mental disorder and/or the participation of their representatives (defense counsel, legal representative); b) priority personal participation in the court hearing of a person suffering from a mental disorder, as the alternative participation of their legal representatives is not always able to compensate for the lack of opportunity for the applicant to express their own position in court.

Survey results: Among the judges we interviewed, 99\% were in favor of the inexpediency of mandatory participation in the court hearing of the person in respect of whom the issue of applying the CMM to them is being considered. In turn, the same number (99\%) of respondents gave an affirmative answer to the question "Do you think that the alternative participation of the defense counsel and the legal representative of the person in respect of whom the application of the CMM is being considered could fully compensate for the absence of such a person in court?". Only one respondent expressed the view that the alternative participation of the defense counsel and the legal representative of the person under consideration of the application of the CMM could not fully compensate for the absence of such a person in the court hearing, and therefore the question of the person's participation in the court hearing should be resolved in each specific case. Thus, the results of the survey show that European approaches today are not always perceived at the level of legal awareness of national law enforcers. In view of this, the implementation of the approaches developed by the ECHR into national law is justified.

2. Establishing the fact of a person's mental illness does not automatically deprive them of their right to personal participation in the trial. This position was expressed in the Case of Proshkin v. Russia, in which the ECHR noted that "although not having an absolute character, the right of being heard enjoys such a prominent place in a democratic society and has such a fundamental value for the protection of an individual against arbitrariness on the part of public authorities, that the mere fact of the individual suffering from a mental illness, as well as his being declared legally incapacitated, cannot automatically lead to the exclusion of the exercise of that right altogether. It is the very weakness of a mentally ill defendant which should enhance the need for supporting his rights. In this context, authorities must show requisite diligence in ensuring the accused's right to be present in an effective manner and must act particularly carefully when infringing upon that right, so as not to place the mentally ill at a disadvantage when compared with other defendants who do enjoy such a right" ( $\$ 102$ of the Case of Proshkin v. Russia) [8].

Thus, the established fact of a person's mental disorder cannot automatically deprive them of the right to participate in the trial. However, a fairly illustrative example of violation of this thesis is the Case of Romanov v. Russia, where the ECHR found that the applicant had never taken part in a court hearing on the basis of a mental illness established by a panel of experts, which found that the applicant had: suffered from a psychological disorder in the form of profound dissociative psychopathy; committed the crime in a state of insanity; had a distorted perception of the circumstances surrounding the criminal proceedings, so he could not give adequate evidence $(\$ 20)$. At the same time, the ECHR examined two circumstances on the basis of which the district court refused to grant the applicant's request for personal participation in the hearing: a) the remand center does not bring persons suffering from a mental disorder to court $(\$ 23)$; b) the testimony of a person who has been declared incompetent is inadmissible evidence ( $\$ 24)$. Analyzing the above circumstances, the ECHR concluded that "in the present case the authorities failed to take any steps to secure the applicant's attendance at the hearings. There is no indication that the applicant displayed any disturbed behavior or that his physical and mental condition otherwise precluded him from appearing before the court. The District Court's argument that the applicant's presence at the hearing was not required in that the testimony of the applicant as a mentally disturbed person could not be accepted as evidence is striking given that it was for the District Court to determine for the first time whether the applicant had committed the offence in a deranged state of mind and assess whether his mental condition required any compulsory medical care" (\$ 109) [7].

At the present stage, the criminal procedure legislation of many states provides for the possibility of restricting the right of a person suffering from a mental disorder to participate in the trial based on the conclusions of forensic psychiatric examination on the nature and extent of their disease (CPC of the Russian Federation (Article 441); CPC of Belarus (Article 445); CPC of Kazakhstan (Article 511); CPC of Moldova (Article 496); CPC of Estonia (Article 400, CPC of Uzbekistan (Article 570)) and others. [1, p. 2448]. However, it should be emphasized that the expert's opinion in criminal proceedings on the CMM actually becomes key evidence. This is due to the fact that the medical aspect is crucial for the court to make both the final decision in the criminal proceedings on the CMM and the interim decision on the possibility of participation in the trial of a person suffering from a mental disorder (Survey results: Among the judges we interviewed, 98\% agreed that in proceedings on the application of the CMM, the conclusion of a forensic psychiatric examination is de facto key evidence). At the same time, a balanced approach of judges to the objective assessment of the expert's conclusion (con- 
clusions) on the mental state of a person acquires special significance, in particular, when deciding on the possibility of such a person's participation in a court hearing. After all, the case law of the ECHR shows examples of rather abstract conclusions of experts on the mental state of a person, which makes it impossible for them to be present during the trial. Thus, in the Case of Anatoliy Rudenko v. Ukraine the ECHR noted that according to the act at the time of the examination the applicant had suffered from "chronic paranoid personality disorder with delusional inclusions". His mental state was considered to be an impediment to his ability to participate effectively in court hearings. According to the expert's report, the applicant behaved casually and amicably, demonstrating a high level of intelligence, good memory and analytical skills, but also a certain superiority and categorical judgment $(\$ 31)$. The ECHR emphasized that there was no compelling reason to prevent the applicant from taking part in the proceedings. Thus, the experts did not provide any explanation as to why the applicant's mental state was considered to prevent him from participating effectively in the court hearings $(\$$ 114) [9]. In the Case of Proshkin v. Russia the ECHR stated that it did not see any convincing evidence to substantiate that the applicant's conduct or mental condition prevented him from attending the trial in person $(\$ 103)$ [8]. In the Case of Romanov v. Russia the ECHR concluded that "the administration did not take any measures to ensure the applicant's presence at the court hearings. There is no evidence that the applicant behaved inappropriately or that his physical or mental condition in any way prevented him from participating in court" $(\$ 106)$ [7].

The ECHR therefore insists on the need for evidence of the conduct of a person which prevents their personal participation in the trial. Thus, when deciding on the legality of a trial in the absence of a person suffering from a mental disorder, judges should critically evaluate the conclusions of experts on the mental state of the person, taking into account other circumstances of the criminal proceedings. For example, in assessing whether a person's absence from a court hearing has been justified, the ECHR takes into account concomitant factors such as the nature and complexity of the issues before the national courts, their importance to the applicant, and whether the person's personal presence posed any threat to others or to themselves, etc. ( $\$ 68$ of the Case of Shtukaturov v. Russia) [4]. In our opinion, the danger of a person to themselves and others should be a criterion for the legitimacy of restricting a person's right to personal participation in court proceedings. Therefore, the conclusions of experts on the mental state of a person, in addition to their diagnosis, should answer the question of the danger degree of a person suffering from a mental disorder.

In the context of this issue, some authors rightly believe that there are various forms of inappropriate behavior that are not covered by the concept of danger, but make it impossible to participate in the trial of a person suffering from a mental disorder. For example, a person gets naked, imitates the voices of animals, etc. Such behavior is incompatible with the observance of the order of the trial and degrades the dignity of the person [10, p. 9]. Agreeing with the above point of view, we believe that in resolving the legality of restricting a person's right to personal participation in the trial, the second criterion is behavior that degrades the honor and dignity of a person suffering from a mental disorder. ${ }^{1}$ In addition, our survey provides an opportunity to add to the list such a criterion as the availability/unavailability of a person for verbal contact and communication with the participants of the court hearing.

Survey results: the answers to the question "If the participation of the person in respect of whom the issue of application of the CMM is considered was not mandatory and this issue would be decided by a judge, then what criteria would be appropriate to take into account when making such a decision?" were divided as follows: only the danger of a person for themselves and others - 22\%; the danger of the person for themselves and others and accessibility/ unavailability of the person for verbal contact and communication with the participants of the court hearing $-78 \%$. At the same time, in resolving this issue $99 \%$ of judges are ready to be guided only by the information reflected in the forensic psychiatric examination and only $1 \%$ of judges are ready to take into account not only the expert's position but also their own assessment of the person's visual perception and verbal communication.

3. A person suffering from a mental disorder has a dual role in court proceedings: he or she is an interested person and, at the same time, the main object of judicial investigation. (See at: $\$ 72$ Case of Shtukaturov v. Russia; $\$ 62$ Case of Zagidulina v. Russia, etc.). Explaining the above position in the Case of Shtukaturov v. Russia, the ECHR stated that a person's participation is necessary not only to state their position on a case, but also for a judge to have their own idea of his or her mental state. In the present case, the Court agreed that "the applicant did indeed have psychiatric problems, but on the basis of the case file he was a relatively independent person. In such circumstances, it was absolutely necessary for the judge to have at least a brief visual contact with the applicant, and preferably his interrogation" $(\$ 72$, 73) [4]. Thus, the manual for prosecutors emphasized the thesis that "A judge must determine if the defendant is fit to plead and to stand trial. This is a determination on the balance of probabilities if the defendant raises the issue, or if he contests it then it is for the prosecution to satisfy the court beyond a reasonable doubt" [11, p. 21].

The criminal procedure legislation of Ukraine provides for the obligatory participation in the court proceedings of a person in respect of whom the issue of application of the CMM is being resolved. This legal requirement in modern judicial practice is provided by videoconference between the courtroom and the psychiatric care facility where the person with the mental disorder is actually staying. In fact, in pursuance of the ECHR's position on the need for a judge to form their own assessment of a person's condition as a result of his or her visual perception and

${ }^{1}$ Although this criterion was not supported by the judges who participated in our survey. 
verbal communication, videoconferencing allows the legal requirement for such a person to participate in court to be met. However, foreign researchers express the position that "Where a defendant is vulnerable, online and virtual procedures are inappropriate. There is limited opportunity for determining whether the defendant fully understands the nature of the plea he or she is tendering or other procedural aspects for which their instructions are required" [12, p. 59].

\section{DISCUSSION}

The issue of personal participation of a person suffering from a mental disorder in the proceedings concerning the application of the CMM from the standpoint of respect for their right to a fair trial (Art. 6 of the Convention) was partially considered by the authors of this article together with Olena A. Leiba [1]. Key aspects of a person's mental health in the context of a fair trial were highlighted in the David Latham's report Mental Health and Fair Trial [12]. The practice of applying procedural law to persons suffering from mental disorders has been analyzed in a handbook for prosecutors - Mental Health Conditions and Disorders: Draft Legal Guidance [11]. In the article of Penny Cooper and Janet Grace, the issues of application in the judicial system of special measures applicable to persons suffering from mental disorders were considered [13]. The study of ensuring the rights and legitimate interests of persons suffering from mental disorders, in the context of international standards of fair trial was carried out in the work of A.L. Osipov [14]. The problems of personal participation of persons in the trial in criminal proceedings concerning the application of the CMM were analyzed in the work of S.N. Shishkov [10]. At the same time, the review of the works allows us to state that today a number of issues related to ensuring the personal participation of a person with a mental disorder in court remain controversial and require further research in terms of the legitimacy of restricting their rights in the court proceedings. This paper highlights the positions of the ECHR in the context of ensuring the right of persons suffering from mental disorders to a fair trial. However, at the present stage it is necessary to comprehend the compliance of law enforcement practice with the specified case law and international standards in general.

\section{CONCLUSIONS}

1. The case law of the ECHR has established certain approaches to the personal participation of a person with a mental disorder in a trial in the context of respect for his or her right to a fair trial: (a) a person suffering from a mental disorder should have access to a court and be heard in person or through any form of legal representation; (b) the establishment of the fact of a person's mental illness does not automatically deprive them of their right to participate personally in the court proceedings; (c) a person suffering from a mental disor- der has a dual role in the trial: he or she is the interested person and, at the same time, the main object of the judicial investigation.

2. The ECHR recognizes: a) personal participation in the trial of a person suffering from a mental disorder and/ or the participation of their representatives (defense counsel, legal representative) as the forms of implementation of the provisions of Art. 6 of the Convention right to a fair trial; b) priority personal participation in the trial of a person suffering from a mental disorder, as the alternative participation of their legal representatives is not always able to compensate for the applicant's lack of opportunity to express their position in court.

3. The conducted research allowed to form three criteria of legality of restriction of the right of the person to personal participation in trial: a) danger of the person for itself and others; b) behavior that degrades the honor and dignity of a person suffering from a mental disorder; c) availability/unavailability of the person for verbal contact and communication with the participants of the court hearing.

\section{REFERENCES}

1. Tyshchenko OI, Leiba $O A$, Titko IA. European standards of respect for human rights in the application of compulsory medical measures in criminal proceedings. Wiad Lek. 2019;LXXII(12)II:2445-2450.

2. Macgregor A, Brown M, Stavert J. Are mental health tribunals operating in accordance with international human rights standards? A systematic review of the international literature. Health Soc Care Community. 2019;27:e494-e513. doi:10.1111/hsc.12749.

3. The European Mental Health Action Plan 2013-2020. WHO Regional Office for Europe. Available from: https://apps.who.int/iris/ handle/10665/175672 [reviewed 2020.07.10].

4. Case of Shtukaturov v. Russia (Application no. 4400905) Judgment of 27 March 2008. Available from: http://hudoc.echr.coe.int/ eng?i=001-85611 [reviewed 2020.07.10].

5. Case of Zagidulina v. Russia (Application no. 11737/06) Judgment of 2 May 2013. Available from: http://hudoc.echr.coe.int/rus?i=001-119043 [reviewed 2020.07.10].

6. Case of Gorshkov v. Ukraine (Application no. 67531/01) Judgment of 8 November 2005. Available from: http://hudoc.echr.coe.int/ eng?i=001-70855 [reviewed 2020.07.10].

7. Case of Romanov v. Russia (Application no. 63993/00) Judgment of 20 October 2005. Available from: http://hudoc.echr.coe.int/ eng?i=001-70685 [reviewed 2020.07.10].

8. Case of Proshkin v. Russia (Application no. 28869/03) Judgment of 7 February 2012. Available from: http://hudoc.echr.coe.int/ eng?i=001-108961 [reviewed 2020.07.10].

9. Case of Anatoliy Rudenko v. Ukraine (Application no. 50264/08) Judgment of 17 April 2014. Available from: http://hudoc.echr.coe.int/ eng?i=001-171853 [reviewed 2020.07.10].

10. ShishkovS. N. Uchastie lits s psihicheskimi rasstroystvami v ugolovnom protsesse [Participation of persons with mental disorders in criminal proceedings]. Russian Psychiatric Journal. 2012;4:4-13. (Ru).

11. Mental Health Conditions and Disorders: Draft Legal Guidance. 2019. 42 p. Available from: https://www.cps.gov.uk/publication/ mental-health-conditions-and-disorders-draft-prosecution-guidance [reviewed 2020.08.15]. 
12. Latham D. Mental health and fair trial. 2017. 114 p. Available from: https://justice.org.uk/wp-content/uploads/2017/11/JUSTICE-MentalHealth-and-Fair-Trial-Report-2.pdf [reviewed 2020.08.15].

13. Cooper P, Grace J. Vulnerable patients going to court: a psychiatrist's guide to special measures. BJPsych Bull. 2016 Aug;40(4):220222. doi:10.1192/pb.bp.115.051508 Available from: https://www. ncbi.nlm.nih.gov/pmc/articles/PMC4967784/ [reviewed 2020.08.15].

14. Osipov A. L. Proizvodstvo o primenenii prinuditelnyih mer meditsinskogo haraktera: natsionalnoe i mezhdunarodno-pravovoe izmereniya [Proceedings on the application of compulsory medical measures: national and international legal dimensions]. Actual problems of Russian law. 2016;3(64):136-142. (Ru).

\section{ORCID and contributionship:}

Vasyl Y. Tatsiy: 0000-0001-6015-3058 ${ }^{\text {A, E, F }}$

Olga I. Tyshchenko: 0000-0003-1551-1367 ${ }^{A, B, D}$

Ivan A. Titko: 0000-0003-4126-6967 C, E, F

\section{Conflict of interest:}

The Authors declare no conflict of interest.

\section{CORRESPONDING AUTHOR}

\section{Ivan A. Titko}

Poltava Law Institute of Yaroslav Mudryi National Law University Pervomaisky Avenue, 5, Poltava 36000, Ukraine tel: +380975150748

e-mail: titko.iv@gmail.com

Received: 02.09 .2020

Accepted: 30.11 .2020 